\title{
DESCRIPTION AND COMPARISON OF GROWTH PARAMETERS IN CHIANINA AND NELORE CATTLE BREEDS*
}

\author{
Sônia Mara Carrijo ${ }^{* *}$ and Francisco A. Moura Duarte ${ }^{2}$
}

\begin{abstract}
Weight data from birth to 18 months of age of Nelore and Chianina, both meat-producing cattle breeds, were analyzed. Data were corrected for significant effects of environment and utilized to estimate genetic parameters through the non-linear von Bertalanffy model. Average values found for growth parameters in Nelore were: mature weight $(A), 312.87 \mathrm{~kg}$; integration constant $(B), 0.49$; maturity rate $(\mathrm{k}), 0.13$; age at inflection point $\left(\mathrm{T}_{(\mathrm{l})}\right), 3.29$ months; weight at inflection point $\left(\mathrm{P}_{(\mathrm{l})}\right), 92.70 \mathrm{~kg}$, and maturity interval (1/k), 8.04 months. For the Chianina animals, the values were $751.38 \mathrm{~kg}, 0.59,0.10,6.64$ months, 222.63 $\mathrm{kg}$, and 10.98 months, respectively. Nelore animals exhibited higher maturity rate, smaller maturity intervals, reaching mature weights younger than Chianina animals, although lighter than these at maturity. Heritability estimates presented low values, mainly for mature weight (0.093 and 0.212$)$, age at inflection point ( 0.062 and 0.202$)$, weight at inflection point $(0.093$ and 0.212$)$ and maturity interval (0.057 and 0.309) (for Nelore and Chianina, respectively). The parameters mature weight and weight at inflection point presented positive genetic correlations with weights at different ages and with similar trends, increasing as age increased, in both breeds. Considering the development period analyzed, from birth to 18 months of age, the parameter maturity rate and the weights at different ages showed genetic correlations which increased until the weight at 150 and 205 days in Nelore and Chianina, respectively, and decreased from these ages on, and the genetic correlations among the parameter maturity interval and the weights at different ages were negative. They decreased until the weights at 150 and 205 days, respectively, in Nelore and Chianina, and increased from these ages on.
\end{abstract}

\section{INTRODUCTION}

Rapid growth until slaughter weight is an important goal for increased meat production. Curves that relate weight or size with age have been used to describe growth. Growth parameters such as mature weight and general maturity rate, estimated from weights taken periodically during the life of the animal, can be used to evaluate development of animals (Brody, 1945).

Growth equations are important in estimating parameters that are biologically uninterpretable, such as age at point of inflection of the growth curve, mature weight and maturity rate (Richards, 1959). These estimates should be used under the hypothesis that they simulate the true biological model (Brown et al., 1972).

The growth functions of Richards, Logística, von Bertalanffy, Gompertz and Brody have been used to describe the Nelore growth (Duarte, 1975). Results suggested the function of von Bertalanffy was the most reasonable in describing the rapid growth and regular development of Nelore cattle. These growth functions have also been used by others (Wada et al., 1983) to describe bovine growth and, according to the authors, of all the growth models

\footnotetext{
* Part of a thesis presented by S.M.C. to the Departamento de Genética e Matemática Aplicada à Biologia, Faculdade de Medicina de Ribeirão Preto, Universidade de São Paulo in partial fulfillment of the requirements for the Master's dregree.

${ }^{l}$ Departamento de Produção Animal, Faculdade de Agronomia "Dr. Francisco Maeda”, Rodovia Jerônimo Nunes Macedo, km 01, Caixa Postal 111, 14500-000 Ituverava, SP, Brasil. Send correspondence to S.M.C.

${ }^{2}$ Departamento de Genética, Faculdade de Medicina de Ribeirão Preto, USP, 14049-900 Ribeirão Preto, SP, Brasil.
}

compared, the von Bertalanffy model was the easiest from a computational point of view.

The curves derived from polynomial and von Bertalanffy models have been used to describe bovine growth (Vaccaro and Rivero, 1985). The authors verified that the von Bertalanffy model resulted in a curve that agreed better with conventional standards of biological growth. The von Bertalanffy function was selected as the most appropriate to evaluate development of beef cattle (López De Torre et al., 1992). The criteria used by the authors to compare the functions of von Bertalanffy, Brody and Richards were computational difficulty, goodness of fit and absence of weight bias at maturity.

From the point of view of bovine development measured in terms of body weight at different ages, growth is a combination of hereditary and environmental effects. High heritability values for mature weight have been found by Northcutt and Wilson (1993) and Bullock et al. (1993). According to the authors, selection based on this characteristic should be effective, and the parameter mature weight can be genetically altered through selection. Adjustment of non-linear models algebraic functions to bovine weights could help detect genetic variability, a fundamentally important factor for genetic selection in breeding programs.

From a genetic aspect, relationships that may eventually exist between the different non-linear growth parameters could provide alternatives for genetic selection programs. Genetic antagonism has been found between mature weight and maturity rate (Taylor and Fitzhugh Jr., 1971; Brown et al., 1972; Nelsen et al., 1982; Perotto, 1992; Bullock et al., 1993), indicating that selection for 
higher maturity rates could lead to lighter weights at maturity. On the other hand, positive and high genetic correlations were found between mature weight and birth weight, as well as between mature weight and yearling weight (Bullock et al., 1993) and, according to Northcutt and Wilson (1993), heifer weight taken before maturity could be used in genetic evaluations of mature weight.

The purpose of the present study was to analyze growth of Nelore (Bos taurus indicus) and Chianina (Bos taurus taurus) animals. The non-linear growth model proposed by von Bertalanffy (1938) was used and the growth parameters were estimated to describe and to compare the development of these two meat-producing bovine breeds.

\section{MATERIAL AND METHODS}

\section{Nelore breed animals}

Nelore animals came from a herd of the Bonsucesso farm, Guararapes, State of São Paulo. They were kept in colonião grass pasture (Panicum maximum), with mineral salt and bone meal supplements available $a d$ libitum. Mating took place in the field, year round; consequently, calves were born during all months of the year. Animals were weighed successively and monthly from birth to 18 months. Only healthy and pasture-fed pure animals (males and females) with a sufficient number of weights were included in the analyses. The sample was composed of 1358 animals, including monthly weight data from 1972 to 1978 and 1980 to 1982 . Data were standardized for birth weight, 90, 150, 205, 365, 455 and 550 days.

\section{Chianina breed animals}

Data referring to the Chianina breed came from six herds from the States of São Paulo and Rio de Janeiro, and one herd from the State of Goiás. Animals were raised under a pasture regime. The reproduction system was by natural service; therefore, calves were born throughout the year. Weights were measured trimesterly from birth until 18 months with a tolerance of 15 days, limiting variation (in days) for age groups. Only healthy and pure animals (males and females) with all consecutive weights until 18 months of age were used. The 257-animal sample included data from 1973 to 1978 and 1980 to 1982 . Trimester weights were standardized for birth weight, 90, 150, 205, 365,455 and 550 days.

\section{Obtaining growth parameters}

The form of the model used in this study was a function of von Bertalanffy, given by the equation: $\mathrm{Yt}=\mathrm{A}$ $\left(1-\mathrm{Be}^{-\mathrm{kt}}\right)^{3}$, where $\mathrm{Yt}$ is weight at time $\mathrm{t}$; $\mathrm{t}$ is the time (age of animal since birth); $\mathrm{A}$ is the asymptotic weight, final weight, or mature weight; B is the integration constant, and $\mathrm{k}$ is the maturity rate or measurement of the exponential function variation.

Model parameters can be interpreted biologically: 1. Asymptotic weight or mature weight is represented by the letter $\mathrm{A}$ in the equation. It is the weight achieved by organisms in growth, which is not surpassed by the elapsing exponential decline in the maturity rate.

2. Inflection point occurs when the estimated maturity rate passes from a growing function to a declining function. In other words, the rate of change in weight is at its maximum and an exponential decline begins with an increasing reduction in the maturity rate.

3 . Slope is represented by the letter $\mathrm{k}$. The estimate of the slope of a non-linear equation is the measurement of the rate of approximation to its asymptotic value. It is referred to as growth rate or maturity rate in relation to mature weight. The value $\mathrm{k}^{-1}$ is the interval of time spent to attain maturity and serves to measure changes in the degree of maturity (Taylor, 1965).

4. Y-intercept is related to the initial weight of the animal. It represents weight $t$, when time equals zero and estimates birth weight. In the model, it is assigned the letter $\mathrm{B}$ and has no biological interpretation. It can be called the integration constant (Richards, 1959; Fitzhugh Jr., 1976).

The von Bertalanffy function parameters were adjusted according to the methodology presented by Draper and Smith (1966).

\section{Standardizing weight}

Monthly weights were standardized for birth weight, 90, 150, 205, 365, 455 and 550 days, using the following methodology (Warwick and Legates, 1979):

$$
\mathrm{P}_{\mathrm{i}}=\text { Pnear }_{\mathrm{i}}+\text { ADG }\left(\mathrm{i}-\text { age } \text { Pnear }_{\mathrm{i}}\right)
$$

where $\mathrm{P}_{i}$ is the standardized weight at standard age $i$, Pnear is the weight nearest to standard age i, ADG is average daily gain considered among the weights after standard age $\mathrm{i}$ and before standard age $\mathrm{i}, \mathrm{i}$ is age to which weight is standardized, and age Pnear $_{i}$, age to weight nearest to standard age $\mathrm{i}$ considering

$$
\mathrm{ADG}=\frac{\mathrm{PP}_{\mathrm{i}}-\mathrm{PA}_{\mathrm{i}}}{\Delta \text { days }}
$$

where ADG is the average daily gain of the time interval in days relative to $\mathrm{PA}_{\mathrm{i}}$ (weight before standard age i) and $\mathrm{PP}_{\mathrm{i}}$ (weight after standard age $\mathrm{i}$ ) and $\Delta$ days the interval in days among the weights considered.

\section{Correcting data for environmental effects}

Corrections for environmental effects were made using the program "Mixed Model Least Squares and Maximum Likelihood Computer Program" (Harvey, 1987). 
For Nelore breed animals,

$$
\mathrm{Y}_{\mathrm{ijk}}=\mu+\mathrm{a}_{\mathrm{i}}+\mathrm{F}_{\mathrm{j}}+\mathrm{e}_{\mathrm{ijk}}
$$

where $Y_{i \mathrm{ik}}$ is the dependent variable; $\mu$ is the general average; $a_{i}$ is a group of random effects (in this case the effect of the bull); $F_{j}$ is the group of fixed effects (month and year of birth, age of mother and sex), and $\mathrm{e}_{\mathrm{ijk}}$ is the experimental error.

For Chianina animals,

$$
\mathrm{Y}_{\mathrm{ijkl}}=\mu+\mathrm{a}_{\mathrm{i}}+\mathrm{b}_{\mathrm{ij}}+\mathrm{F}_{\mathrm{k}}+\mathrm{e}_{\mathrm{ijk} \mathrm{l}}
$$

where $Y_{\mathrm{ijk1}}$ is the dependent variable; $\mu$ is the general average, $a_{i}$ is the group of random effects (representing herds); $b_{i j}$ is a hierarchical random effect (bull within the herd); $F_{k}$ is other group of fixed effects (year and month of birth, age of mother and sex), and $\mathrm{e}_{\mathrm{ijkl}}$ is the experimental error.

\section{Estimates of heritability and genetic, phenotypic and environmental correlations}

Estimates of heritability and genetic, phenotypic and environmental correlations were obtained through the methodology described in specialized literature. Heritability estimates were based on interclass correlations between paternal half brothers. Genetic, phenotypic and en- vironmental correlations among growth parameters were based on variance and covariance components between and among sires and error, respectively.

\section{RESULTS AND DISCUSSION}

\section{Environmental variation factors of growth parameters}

For weights observed in Nelore animals, analysis of variance (Table I) showed that effects of the bull, year and month of birth, age of mother and sex were significant for all parameters. These results agreed with those obtained by other authors. Growth parameters have been influenced by effect of the age of the mother (Quaas, 1983; Wada and Nishida, 1987; Northcutt et al., 1994). The effect of the season was significant for the maturity rate (Nuru et al., 1981), as well as for mature weight and maturity rate (McLaren et al., 1982). The year of birth proved to be significant for the growth parameters and the effect of the bull's lineage for mature weight (DeNise, 1982; Quaas, 1983). The effects of the bull, month and year of birth and sex have been significant for the parameters mature weight and integration constant, while the maturity rate had been influenced by the effect of the bull (Bianchini Sobrinho and Duarte, 1991; Souza and Bianchini Sobrinho, 1994).

Table I

Analysis of variance for estimated growth parameters by von Bertalanffly's model,

\begin{tabular}{|c|c|c|c|c|c|c|c|}
\hline \multirow{2}{*}{$\begin{array}{c}\text { Sources of } \\
\text { variation }\end{array}$} & \multirow{2}{*}{$\begin{array}{l}\text { Degrees of } \\
\text { freedom }\end{array}$} & \multicolumn{6}{|c|}{ Mean squares } \\
\hline & & A & B & $\mathrm{k}$ & $\mathrm{T}_{(\mathrm{I})}$ & $P_{(I)}$ & $1 / \mathrm{k}$ \\
\hline Bull & 23 & $14039.887^{*}$ & $0.003 *$ & $0.003 *$ & $8.529 *$ & $1232.582 *$ & $22.703 *$ \\
\hline Year of birth & 9 & $92342.452 *$ & $0.012 *$ & $0.022 *$ & $24.476^{*}$ & $8106.882 *$ & $82.630 *$ \\
\hline Month of birth & 11 & $56258.279^{*}$ & $0.004 *$ & $0.013 *$ & $20.766^{*}$ & $4938.998^{*}$ & $79.305 *$ \\
\hline Age of mother & 8 & $18109.216^{*}$ & $0.004 *$ & $0.004 *$ & $16.966 *$ & $1589.834^{*}$ & $42.034 *$ \\
\hline Sex & 1 & $1446898.060 *$ & $0.065 *$ & $0.082 *$ & $121.331 *$ & $127025.338^{*}$ & $247.554 *$ \\
\hline Residual & 1305 & 6984.821 & 0.001 & 0.001 & 4.815 & 613.207 & 12.597 \\
\hline
\end{tabular}
obtained from Nelore weight data.

* Significant, $\mathrm{P}<0.10$.

Table II

Analysis of variance for estimated growth parameters by von Bertalanffy's model,

\begin{tabular}{|c|c|c|c|c|c|c|c|}
\hline \multirow{2}{*}{$\begin{array}{c}\text { Sources of } \\
\text { variation }\end{array}$} & \multirow{2}{*}{$\begin{array}{l}\text { Degrees of } \\
\text { freedom }\end{array}$} & \multicolumn{6}{|c|}{ Mean squares } \\
\hline & & A & B & $\mathrm{k}$ & $\mathrm{T}_{(\mathrm{I})}$ & $\mathrm{P}_{(\mathrm{I})}$ & $1 / \mathrm{k}$ \\
\hline Herd & 6 & 169880.408 & 0.005 & 0.003 & 23.205 & 14914.054 & 45.243 \\
\hline "Bull/Herd & 25 & $134701.277 *$ & $0.004 *$ & $0.002 *$ & $23.434 *$ & $11825.626^{*}$ & 39.384 \\
\hline Year of birth & 8 & 45379.905 & 0.001 & 0.001 & 9.283 & 3983.968 & 19.894 \\
\hline Month of birth & 11 & 43891.854 & 0.002 & 0.001 & 11.356 & 3853.330 & 19.998 \\
\hline Age of mother & 7 & 103592.265 & $0.004 *$ & 0.002 & $22.005 *$ & 9094.521 & 31.497 \\
\hline Sex & 1 & $4668169.632 *$ & $0.107 *$ & $0.005^{*}$ & $118.692 *$ & $409825.577 *$ & $69.342 *$ \\
\hline Residual & 198 & 67443.577 & 0.002 & 0.001 & 12.086 & 5920.972 & 19.597 \\
\hline
\end{tabular}
obtained from Chianina weight data.

* Significant, $\mathrm{P}<0.10$. 
Table III

Estimates of heritability of growth parameters estimated by the model of von Bertalanffy in Nelore animals.

\begin{tabular}{|ccc|}
\hline Parameters & Heritabilities & Standard error \\
\hline $\mathrm{A}$ & 0.093 & 0.047 \\
$\mathrm{~B}$ & 0.236 & 0.084 \\
$\mathrm{k}$ & 0.129 & 0.057 \\
$\mathrm{~T}_{\text {(I) }}$ & 0.062 & 0.038 \\
$\mathrm{P}_{(\mathrm{I})}$ & 0.093 & 0.047 \\
$1 / \mathrm{k}$ & 0.057 & 0.037 \\
\hline
\end{tabular}

Table IV

Estimates of heritability of growth parameters estimated by the model of von Bertalanffy in Chianina animals.

\begin{tabular}{|ccc|}
\hline Parameters & Heritabilities & Standard error \\
\hline $\mathrm{A}$ & 0.212 & 0.176 \\
$\mathrm{~B}$ & 0.542 & 0.228 \\
$\mathrm{k}$ & 0.330 & 0.196 \\
$\mathrm{~T}_{(\mathrm{I})}$ & 0.202 & 0.174 \\
$\mathrm{P}_{(\mathrm{I})}$ & 0.212 & 0.176 \\
$1 / \mathrm{k}$ & 0.309 & 0.192 \\
\hline
\end{tabular}

Statistical analysis applied to growth parameter values obtained from Chianina animal weights (Table II) showed that the effect of the bull within the herd and sex were significant for all parameters, and the effect of age of the mother proved to be significant for the parameters integration constant and age at inflection point.

\section{Heritability estimates for growth parameters}

The heritability estimates found for Nelore animals were low (Table III). For the Chianina, heritability estimates were also low (Table IV), mainly for mature weight, age at inflection point, weight at inflection point and maturity interval. Such results suggest that selection for growth, based solely on curve parameters, may not lead to a satisfactory response. These results agreed with those obtained in the literature (Bianchini Sobrinho and Duarte, 1991; Souza and Bianchini Sobrinho, 1994). However, high heritabilities for the growth parameters were found (Wada and Nishida, 1987). High heritabilities for the parameter mature weight were observed by others (Northcutt and Wilson, 1993; Bullock et al., 1993), suggesting that this parameter could be genetically altered by selection.

Table V

Average values of growth parameters estimated by the model of von Bertalanffy obtained from growth data adjusted for significant environmental effects in Nelore animals.

\begin{tabular}{|c|c|c|c|c|c|c|c|}
\hline \multirow[b]{3}{*}{ Bull's number } & \multirow[b]{3}{*}{ Son No. } & \multicolumn{6}{|c|}{ Parameters } \\
\hline & & $\mathrm{A}_{(\mathrm{kg})}$ & B & $\mathrm{k}$ & $\mathrm{T}_{\text {(I) (months) }}$ & $P_{(\mathrm{I})(\mathrm{kg})}$ & $1 / \mathrm{k}_{\text {(months) }}$ \\
\hline & & & & & & & \\
\hline 41 & 144 & 321.27 & 0.492 & 0.127 & 3.359 & 95.191 & 8.442 \\
\hline 43 & 38 & 321.92 & 0.515 & 0.134 & 3.435 & 95.385 & 7.812 \\
\hline 44 & 33 & 334.94 & 0.514 & 0.137 & 4.327 & 99.243 & 8.919 \\
\hline 45 & 98 & 310.70 & 0.493 & 0.142 & 3.255 & 92.060 & 7.895 \\
\hline 46 & 74 & 322.13 & 0.485 & 0.137 & 2.961 & 95.446 & 7.794 \\
\hline 48 & 14 & 332.25 & 0.505 & 0.138 & 3.297 & 98.446 & 7.722 \\
\hline 51 & 33 & 328.58 & 0.497 & 0.127 & 3.320 & 97.357 & 8.226 \\
\hline 54 & 70 & 298.11 & 0.484 & 0.145 & 2.785 & 88.328 & 7.284 \\
\hline 57 & 16 & 323.27 & 0.506 & 0.136 & 3.232 & 95.784 & 7.772 \\
\hline 58 & 15 & 365.51 & 0.497 & 0.112 & 4.724 & 108.30 & 10.953 \\
\hline 59 & 63 & 312.41 & 0.496 & 0.135 & 3.389 & 92.565 & 8.176 \\
\hline 61 & 55 & 280.80 & 0.496 & 0.144 & 2.939 & 83.199 & 7.285 \\
\hline 64 & 44 & 282.24 & 0.492 & 0.157 & 2.916 & 83.627 & 7.177 \\
\hline 66 & 34 & 311.76 & 0.497 & 0.132 & 3.257 & 92.372 & 7.969 \\
\hline 68 & 19 & 303.06 & 0.501 & 0.138 & 3.085 & 89.796 & 7.551 \\
\hline 69 & 22 & 271.35 & 0.486 & 0.162 & 2.439 & 80.399 & 6.376 \\
\hline 89 & 59 & 331.85 & 0.504 & 0.124 & 3.761 & 98.327 & 8.841 \\
\hline 299 & 49 & 320.48 & 0.499 & 0.143 & 3.048 & 94.957 & 7.484 \\
\hline 473 & 59 & 297.90 & 0.480 & 0.160 & 2.666 & 88.267 & 7.079 \\
\hline 494 & 94 & 311.64 & 0.501 & 0.134 & 3.310 & 92.337 & 7.958 \\
\hline 605 & 127 & 326.93 & 0.493 & 0.129 & 3.896 & 96.868 & 9.334 \\
\hline 739 & 65 & 310.49 & 0.495 & 0.134 & 3.144 & 91.997 & 7.949 \\
\hline 800 & 42 & 298.85 & 0.506 & 0.123 & 3.596 & 88.548 & 8.527 \\
\hline 806 & 91 & 298.50 & 0.503 & 0.141 & 3.131 & 88.445 & 7.475 \\
\hline $\begin{array}{l}\text { Total number } \\
\text { of animals }\end{array}$ & 1358 & & & & & & \\
\hline \multicolumn{2}{|c|}{$\begin{array}{l}\text { General average of } \\
\text { growth parameters }\end{array}$} & 312.87 & 0.496 & 0.137 & 3.297 & 92.702 & 8.048 \\
\hline
\end{tabular}


Table VI

Average values of growth parameters estimated by the model of von Bertalanffy obtained from growth data adjusted for significant environmental effects in Chianina animals.

\begin{tabular}{|c|c|c|c|c|c|c|c|}
\hline \multirow[b]{3}{*}{ Bull's number } & \multirow[b]{3}{*}{ Son No. } & \multicolumn{6}{|c|}{ Parameters } \\
\hline & & $\mathrm{A}_{(\mathrm{kg})}$ & B & $\mathrm{k}$ & $\mathrm{T}_{(\mathrm{I}) \text { ( months) }}$ & $P_{(\mathrm{I})(\mathrm{kg})}$ & $1 / \mathrm{k}_{\text {(months) }}$ \\
\hline & & & & & & & \\
\hline 89 & 15 & 806.43 & 0.610 & 0.096 & 6.745 & 238.94 & 11.000 \\
\hline 91 & 18 & 719.17 & 0.599 & 0.108 & 5.702 & 213.09 & 9.602 \\
\hline 110 & 3 & 1025.40 & 0.606 & 0.092 & 6.495 & 303.83 & 10.829 \\
\hline 134 & 4 & 849.98 & 0.569 & 0.093 & 11.621 & 251.85 & 18.246 \\
\hline 177 & 4 & 606.34 & 0.590 & 0.110 & 5.766 & 179.66 & 9.955 \\
\hline 234 & 4 & 739.87 & 0.567 & 0.126 & 4.343 & 219.22 & 8.113 \\
\hline 328 & 3 & 930.25 & 0.616 & 0.072 & 8.925 & 275.63 & 14.468 \\
\hline 335 & 12 & 640.37 & 0.585 & 0.101 & 6.217 & 189.74 & 10.717 \\
\hline 439 & 7 & 703.84 & 0.579 & 0.127 & 4.818 & 208.54 & 8.492 \\
\hline 459 & 9 & 756.62 & 0.598 & 0.130 & 4.963 & 224.18 & 8.288 \\
\hline 462 & 3 & 512.86 & 0.542 & 0.140 & 3.479 & 151.96 & 7.119 \\
\hline 544 & 5 & 649.93 & 0.570 & 0.081 & 9.446 & 192.57 & 15.923 \\
\hline 548 & 4 & 602.00 & 0.572 & 0.084 & 6.614 & 178.37 & 12.122 \\
\hline 551 & 10 & 896.20 & 0.617 & 0.075 & 8.864 & 265.54 & 14.225 \\
\hline 608 & 4 & 645.83 & 0.568 & 0.106 & 5.387 & 191.36 & 9.893 \\
\hline 645 & 6 & 674.96 & 0.570 & 0.104 & 5.455 & 199.99 & 10.060 \\
\hline 651 & 11 & 719.01 & 0.594 & 0.112 & 6.464 & 213.04 & 10.601 \\
\hline 711 & 5 & 777.38 & 0.621 & 0.074 & 8.518 & 230.34 & 13.596 \\
\hline 714 & 3 & 623.45 & 0.591 & 0.117 & 6.297 & 184.73 & 10.446 \\
\hline 901 & 6 & 872.67 & 0.597 & 0.117 & 6.197 & 258.57 & 10.194 \\
\hline 908 & 13 & 792.51 & 0.597 & 0.112 & 5.450 & 234.82 & 9.240 \\
\hline 1151 & 6 & 893.44 & 0.616 & 0.090 & 8.052 & 264.72 & 12.677 \\
\hline 1188 & 18 & 727.94 & 0.628 & 0.103 & 6.946 & 215.68 & 10.742 \\
\hline 1229 & 7 & 554.78 & 0.542 & 0.132 & 4.670 & 164.38 & 9.094 \\
\hline 1386 & 3 & 435.39 & 0.529 & 0.138 & 3.332 & 129.01 & 7.228 \\
\hline 1569 & 10 & 935.93 & 0.628 & 0.076 & 9.020 & 277.31 & 13.966 \\
\hline 1570 & 11 & 741.56 & 0.602 & 0.103 & 6.421 & 219.72 & 10.664 \\
\hline 1700 & 12 & 748.61 & 0.611 & 0.095 & 6.990 & 221.81 & 11.293 \\
\hline 1701 & 12 & 888.38 & 0.626 & 0.098 & 7.684 & 263.23 & 11.777 \\
\hline 1702 & 17 & 716.08 & 0.588 & 0.109 & 6.143 & 212.17 & 10.456 \\
\hline 1906 & 6 & 880.84 & 0.620 & 0.087 & 8.874 & 260.99 & 13.679 \\
\hline 2440 & 6 & 620.25 & 0.595 & 0.094 & 6.374 & 183.78 & 10.888 \\
\hline $\begin{array}{l}\text { Total number } \\
\text { of animals }\end{array}$ & 257 & & & & & & \\
\hline \multicolumn{2}{|c|}{$\begin{array}{l}\text { General average of } \\
\text { growth parameters }\end{array}$} & 751.38 & 0.598 & 0.103 & 6.640 & 222.63 & 10.989 \\
\hline
\end{tabular}

\section{Growth parameter values obtained with the von Bertalanffy model}

In addition to the basic growth parameters, such as mature weight $(\mathrm{A})$, maturity rate $(\mathrm{k})$ and integration constant (B), the model can generate diverse growth measurements that permit the study of variations among the developmental standards that may not be reflected in the basic parameters. Among these are age at inflection point of the growth curve $\left(\mathrm{T}_{(\mathrm{I})}\right)$, weight at inflection point of the growth curve $\left(\mathrm{P}_{(\mathrm{I})}\right)$ and average maturity interval $(1 / \mathrm{k})$. This additional information allows more precise comparisons among the developmental standards. These statistics proved to be useful information regarding bovine growth (Duarte, 1975).

Average values were obtained for growth parameters of Nelore (Table V) and Chianina (Table VI) breed animals. Note that average mature weight (A) estimated for the Chianina breed $(751.38 \mathrm{~kg})$ is more than twice the value estimated for the Nelore breed $(312.87 \mathrm{~kg})$. Although presenting heavier average mature weights, Chianina exhibited maturity rates $(\mathrm{k})$ inferior to those of Nelore by approximately $25 \%$, which is deemed relevant considering the magnitude of this parameter.

Parameters A and $\mathrm{k}$ showed a pronounced inverse relationship in both breeds. Animals with heavier average A values presented the slowest average $k$ values. On the other hand, those that grew with fast maturity rates were lighter at maturity. An inverse relationship between mature weight and maturity rate was also observed in the literature (Taylor and Fitzhugh Jr., 1971; Brown et al., 1972; Duarte, 1975; Nelsen et al., 1982; Perotto, 1992; Bullock et al., 1993; Perotto et al., 1994).

An inverse relationship between parameters $\mathrm{k}$ and $1 / \mathrm{k}$ was observed in both breeds. These observations agree 
Table VII

Estimates of genetic, phenotypic and environmental correlations between growth parameters estimated by the model of von Bertalanffy for Nelore animals.

\begin{tabular}{|ccccc|}
\hline \multirow{2}{*}{ Parameters } & \multicolumn{4}{c|}{ Correlations } \\
\cline { 2 - 5 } & Genetic & $\begin{array}{c}\text { Standard } \\
\text { error }\end{array}$ & Phenotypic & Environmental \\
\hline $\mathrm{A}-\mathrm{B}$ & 0.463 & 0.236 & 0.718 & 0.780 \\
$\mathrm{k}$ & -0.728 & 0.364 & -0.700 & -0.698 \\
$\mathrm{~T}_{(\mathrm{I})}$ & 0.501 & 0.278 & 0.845 & 0.874 \\
$\mathrm{P}_{(\mathrm{I})}$ & 1.000 & 0.000 & 1.000 & 1.000 \\
$1 / \mathrm{k}$ & 0.500 & 0.287 & 0.791 & 0.816 \\
& & & & \\
$\mathrm{~B}-\mathrm{k}$ & -0.599 & 0.268 & -0.529 & -0.521 \\
$\mathrm{~T}_{(\mathrm{I})}$ & 0.810 & 0.147 & 0.715 & 0.730 \\
$\mathrm{P}_{(\mathrm{I})}$ & 0.463 & 0.236 & 0.718 & 0.780 \\
$1 / \mathrm{k}$ & 0.440 & 0.284 & 0.552 & 0.591 \\
& & & & \\
$\mathrm{k}-\mathrm{T}_{(\mathrm{I})}$ & -0.795 & 0.441 & -0.724 & -0.723 \\
$\mathrm{P}_{(\mathrm{I})}$ & -0.728 & 0.364 & -0.700 & -0.698 \\
$1 / \mathrm{k}$ & -0.838 & 0.480 & -0.819 & -0.824 \\
& & & & \\
$\mathrm{~T}_{(\mathrm{I})}-\mathrm{P}_{(\mathrm{I})}$ & 0.501 & 0.278 & 0.845 & 0.874 \\
$1 / \mathrm{k}$ & 0.873 & 0.093 & 0.957 & 0.962 \\
& & & & \\
$\mathrm{P}_{(\mathrm{I})}-1 / \mathrm{k}$ & 0.500 & 0.287 & 0.791 & 0.816 \\
\hline
\end{tabular}

with other authors' results (Brown et al., 1976; López De Torre and Rankin, 1978; Perotto et al., 1994). Note that the Chianina breed had slower maturity rates, and consequently, their maturity intervals were longer than Nelore.

Average values for parameters $\mathrm{T}_{(\mathrm{I})}, \mathrm{P}_{\text {(I) }}$ and $1 / \mathrm{k}$ were respectively: 3.297 months, $92.702 \mathrm{~kg}$ and 8.048 months for Nelore animals and 6.640 months, $222.63 \mathrm{~kg}$ and 10.989 months for Chianina animals. Observe that Nelore breed animals were younger and lighter at inflection point and at maturity than Chianina breed.

\section{Estimates of correlation}

\section{1) Nelore breed}

Correlations among growth parameters

Correlations among growth parameters of Nelore animals were estimated (Table VII). Observe that parameter $\mathrm{k}$ exhibited a negative genetic correlation coefficient with $\mathrm{A}$, indicating that selection for faster maturity rates could result in a reduction in mature weights. Negative genetic correlation coefficients between maturity rate and mature weight were also found in the literature (Taylor and Fitzhugh Jr., 1971; Brown et al., 1972; Calo et al., 1973; Duarte, 1975; López De Torre and Rankin, 1978; Nelsen et al., 1982; Perotto, 1992).

The parameter $\mathrm{k}$ was negatively correlated genetically with $1 / \mathrm{k}$, agreeing with results found in the literature (Brown et al., 1976; López De Torre and Rankin, 1978;
Perotto et al., 1994). This result indicates that selection for faster maturity rates could result in individuals that reach maturity much more quickly. The parameter $\mathrm{k}$ was negatively correlated genetically with $\mathrm{B}, \mathrm{P}_{(\mathrm{I})}$ and $\mathrm{T}_{(\mathrm{I})}$, meaning that selection for faster maturity rates could result in lower birth weights and weight at inflection point, and therefore, could reduce the age at inflection point.

Parameter A showed positive genetic correlation with $1 / \mathrm{k}$, agreeing with Duarte (1975) and Bullock et al. (1993). The genetic correlation among $\mathrm{A}$ and $\mathrm{T}_{\text {(I) }}$ was also positive, and there was an equal genetic correlation of +1.0 between parameters $\mathrm{A}$ and $\mathrm{P}_{\mathrm{CI}}$, suggesting that selection for heavier weights at the inflection could increase mature weight; however, animals would also be older at maturity.

The parameter $1 / \mathrm{k}$ had positive genetic correlations with $\mathrm{B}, \mathrm{T}_{(\mathrm{I})}$ and $\mathrm{P}_{(\mathrm{I})}$. Genetic correlations were positive between $\mathrm{B}$ and $\mathrm{T}_{(\mathrm{I})}, \mathrm{B}$ and $\mathrm{P}_{(\mathrm{I})}$, as well as between $\mathrm{T}_{(\mathrm{I})}$ and $\mathrm{P}_{(\mathrm{I})}$, meaning that selection for heavier birth weights could result in older and heavier animals at inflection point, and selection for younger animals at inflection point could reduce weight at inflection point.

Correlations among different parameters and weights at diverse ages

The correlations among different parameters and weights at diverse ages of Nelore animals were obtained (Table VIII). Examine that mature weight had positive genetic correlation with birth weight. This result was also verified by Northcutt et al. (1994). This value tended to increase as age increased, agreeing with Bullock et al. (1993). For maturity rate, agreeing with results in the literature which indicate negative genetic correlation between parameters A and $\mathrm{k}$, one would expect that genetic correlation between $\mathrm{k}$ and weight at different ages would tend to decrease as age increased. However, in this study such correlations tended to grow until 150 days of age, after which values tended to decrease.

For the period studied, from birth to 18 months, the results indicate that selection could be made at 150 days, choosing animals with faster maturity rates without reducing mature weight. Selection after or before 150 days for heavier weights could result in choosing animals with slower maturity rates that reach mature weight older.

Genetic correlation for the parameter $1 / \mathrm{k}$ tended to decrease until 150 days of age, after which it tended to increase with age even though values were negative. Considering the time interval studied, selection performed at 150 days, aiming to decrease the maturity interval, could result in heavier and younger animals at maturity. Selection for shorter maturity intervals before or after 150 days could result in animals that reach mature weight younger, and are therefore, lighter at maturity.

Among $\mathrm{P}_{(\mathrm{I})}$ and weight at different ages, the genetic correlations were positive and tended to increase with age, suggesting that selection for heavier weights at in- 
Table VIII

Estimates of genetic, phenotypic and environmental correlations between growth parameters estimated by the model of von Bertalanffy and weight at different ages for Nelore animals.

\begin{tabular}{|c|c|c|c|c|c|}
\hline \multirow[t]{2}{*}{ Parameters } & \multirow{2}{*}{$\begin{array}{c}\text { Weight at } \\
\text { different ages }\end{array}$} & \multicolumn{4}{|c|}{ Correlations } \\
\hline & & Genetic & Standard error & Phenotypic & Environmental \\
\hline \multirow[t]{7}{*}{ A - } & BW* & 0.217 & 0.278 & 0.169 & 0.195 \\
\hline & P 090 & 0.463 & 0.260 & 0.032 & -0.067 \\
\hline & P 150 & 0.438 & 0.271 & -0.014 & -0.110 \\
\hline & P 205 & 0.467 & 0.266 & 0.001 & -0.096 \\
\hline & P 365 & 0.721 & 0.189 & 0.288 & 0.210 \\
\hline & P 455 & 0.785 & 0.157 & 0.441 & 0.389 \\
\hline & P 550 & 0.835 & 0.130 & 0.544 & 0.505 \\
\hline \multirow[t]{7}{*}{ B - } & BW & -0.728 & 0.158 & -0.352 & -0.142 \\
\hline & P 090 & -0.402 & 0.235 & -0.336 & -0.313 \\
\hline & P 150 & -0.346 & 0.244 & -0.250 & -0.217 \\
\hline & P 205 & -0.312 & 0.246 & -0.138 & -0.076 \\
\hline & P 365 & 0.078 & 0.260 & 0.252 & 0.315 \\
\hline & P 455 & 0.252 & 0.246 & 0.362 & 0.399 \\
\hline & P 550 & 0.092 & 0.262 & 0.339 & 0.422 \\
\hline \multirow[t]{7}{*}{$\mathrm{k}-$} & BW & 0.190 & 0.265 & 0.019 & -0.056 \\
\hline & P 090 & 0.177 & 0.271 & 0.372 & 0.444 \\
\hline & P 150 & 0.203 & 0.271 & 0.438 & 0.510 \\
\hline & P 205 & 0.171 & 0.275 & 0.431 & 0.508 \\
\hline & Р 365 & -0.130 & 0.282 & 0.115 & 0.179 \\
\hline & P 455 & -0.279 & 0.277 & -0.093 & -0.051 \\
\hline & P 550 & -0.326 & 0.278 & -0.221 & -0.201 \\
\hline \multirow[t]{7}{*}{$\mathrm{T}_{(\mathrm{I})}-$} & BW & -0.622 & 0.267 & -0.100 & 0.031 \\
\hline & P 090 & -0.507 & 0.324 & -0.394 & -0.410 \\
\hline & P 150 & -0.532 & 0.337 & -0.469 & -0.489 \\
\hline & P 205 & -0.510 & 0.339 & -0.462 & -0.484 \\
\hline & P 365 & -0.193 & 0.339 & -0.194 & -0.207 \\
\hline & P 455 & -0.047 & 0.342 & -0.044 & -0.046 \\
\hline & P 550 & -0.045 & 0.342 & 0.042 & 0.058 \\
\hline \multirow[t]{7}{*}{$\mathrm{P}_{(\mathrm{I})}-$} & BW & 0.217 & 0.278 & 0.169 & 0.195 \\
\hline & P 090 & 0.463 & 0.260 & 0.032 & -0.067 \\
\hline & P 150 & 0.438 & 0.271 & -0.014 & -0.110 \\
\hline & P 205 & 0.467 & 0.266 & 0.001 & -0.096 \\
\hline & Р 365 & 0.721 & 0.189 & 0.288 & 0.210 \\
\hline & P 455 & 0.785 & 0.157 & 0.441 & 0.389 \\
\hline & P 550 & 0.835 & 0.130 & 0.544 & 0.505 \\
\hline \multirow[t]{7}{*}{$1 / \mathrm{k}-$} & BW & -0.268 & 0.317 & -0.003 & 0.074 \\
\hline & P 090 & -0.389 & 0.344 & -0.403 & -0.444 \\
\hline & P 150 & -0.468 & 0.357 & -0.514 & -0.557 \\
\hline & P 205 & -0.446 & 0.361 & -0.535 & -0.586 \\
\hline & P 365 & -0.249 & 0.351 & -0.304 & -0.333 \\
\hline & P 455 & -0.150 & 0.350 & -0.134 & -0.139 \\
\hline & P 550 & -0.024 & 0.350 & -0.010 & -0.008 \\
\hline
\end{tabular}

*BW- Birth weight.

flection point could result in heavier mature weights, which agrees with Duarte (1975).

Parameter B had low genetic correlation coefficients with weight at different ages, which although negative until the weight at 205 days, tended to increase with age. Genetic correlations between $\mathrm{T}_{(\mathrm{I})}$ and weight at different ages tended to increase with age, even though values were negative.

For the period analyzed, the practice of selection for heavier weights at 150 days could lead to obtainment of animals that grow with faster maturity rates, and are heavier and younger at inflection point and maturity.

\section{2) Chianina breed}

Correlations among growth parameters

Correlation coefficients among growth parameters of Chianina animals were estimated (Table IX). The genetic correlation between $\mathrm{A}$ and $\mathrm{k}$ was negative, agreeing with results found in literature (Talyor and Fitzhugh Jr., 1971; Brown et al., 1972; Calo et al., 1973; Duarte, 1975; López De Torre and Rankin, 1978; Nelsen et al., 1982; Perotto, 1992). The genetic correlation between $\mathrm{k}$ and $\mathrm{P}_{(\mathrm{I})}$ 
was also negative. Such results indicate that selection to faster maturity rates could lead to lighter weights at inflection point and maturity. The parameters $\mathrm{A}$ and $\mathrm{P}_{(\mathrm{I})}$ had equal genetic correlation +1.0 . These results indicate that selection for heavier weights at inflection point could lead to heavier mature weights.

Parameter A presented negative genetic correlation with $\mathrm{T}_{(\mathrm{I})}$. Genetic correlation between $\mathrm{P}_{(\mathrm{I})}$ and $\mathrm{T}_{(\mathrm{I})}$ was also negative, meaning that selection for younger animals at inflection point could increase weight at inflection point and mature weight. These results did not agree with those found in literature.

Between $1 / \mathrm{k}$ and $\mathrm{k}$ the genetic correlation was negative, indicating that with faster maturity rates, maturity is reached at a shorter interval of time. These results were also observed by Brown et al. (1976), López De Torre and Rankin (1978) and Perotto et al. (1994). The parameter 1/k was negatively correlated genetically with parameters A, B and $\mathrm{P}_{(\mathrm{II}}$, suggesting that selection for shorter maturity intervals could increase birth weight and weight at inflection point. These results do not agree with those found in literature. However, high standard errors were found suggesting that interpretations should be made cautiously. One of the factors that could explain this finding could be related to the small number of observations in the sample.

The parameter $1 / \mathrm{k}$ was positively correlated genetically with $\mathrm{T}_{\mathrm{I}}$, meaning that selection for shorter maturity intervals could reduce age at inflection point. Parameters $\mathrm{B}$ and $\mathrm{P}_{\text {(I) }}$ had positive genetic correlations with $\mathrm{A}$, indicating

Table IX

Estimates of genetic, phenotypic and environmental correlations between growth parameters estimated by the model of von Bertalanffy for Chianina animals.

\begin{tabular}{|c|c|c|c|c|}
\hline \multirow[t]{2}{*}{ Parameters } & \multicolumn{4}{|c|}{ Correlations } \\
\hline & Genetic & Standard error & Phenotypic & Environmental \\
\hline$A-B$ & 0.618 & 0.243 & 0.827 & 1.029 \\
\hline $\mathrm{k}$ & -0.245 & 0.669 & -0.711 & -0.890 \\
\hline$T_{(1)}$ & -0.040 & 0.711 & 0.864 & 1.100 \\
\hline $\mathrm{P}_{(\mathrm{I})}$ & 1.000 & 0.000 & 1.000 & 1.000 \\
\hline $1 / \mathrm{k}$ & -0.138 & 0.544 & 0.815 & 1.153 \\
\hline$B-k$ & -0.415 & 0.499 & -0.732 & -1.006 \\
\hline $\mathrm{T}_{(1)}$ & 0.217 & 0.423 & 0.761 & 1.140 \\
\hline$P_{(I)}$ & 0.618 & 0.243 & 0.827 & 1.029 \\
\hline $1 / \mathrm{k}$ & -0.023 & 0.415 & 0.680 & 1.225 \\
\hline$k-T_{(I)}$ & -1.015 & 0.969 & -0.793 & -0.726 \\
\hline $\mathrm{P}_{(\mathrm{I})}$ & -0.245 & 0.669 & -0.711 & -0.890 \\
\hline $1 / \mathrm{k}$ & -0.930 & 0.763 & -0.816 & -0.763 \\
\hline $\mathrm{T}_{(1)}-\mathrm{P}_{(1)}$ & -0.040 & 0.711 & 0.864 & 1.100 \\
\hline $1 / \mathrm{k}$ & 0.973 & 0.026 & 0.988 & 1.003 \\
\hline$P_{(I)}-1 / k$ & -0.138 & 0.544 & 0.815 & 1.153 \\
\hline
\end{tabular}

that selection for heavier birth weights could result in heavier weights at inflection point and heavier mature weights.

Correlations among different parameters and weight at different ages

Correlation coefficients between different parameters and weight at different ages of Chianina animals were obtained (Table $\mathrm{X}$ ). Note that standard error values varied between \pm 0.25 and \pm 0.50 , which can be considered high. The small sample size of Chianina could have resulted in these values. Genetic correlations between A and weight at different ages tended to increase with age. This result agreed with those of Bullock et al. (1993). Therefore, selection for heavier weights at any age could lead to heavier mature weights.

The parameter $\mathrm{k}$ and weight at different ages presented genetic correlations which increased until 205 days of age; afterwards, it decreased. For this group of animals and the interval of ages analyzed, results suggested that selection for heavier weights at 205 days could lead to faster maturity rates without reducing mature weight. Selection for heavier weights, before or after this age, could result in animals with slower maturity rates and lighter mature weights.

The parameters $\mathrm{A}$ and $\mathrm{P}_{(\mathrm{I})}$ showed genetic correlations with weight at different ages which were equal and tended to increase as age increased, inferring that evaluation of genetic potential for weight at maturity could be made early, reducing the interval between generations and, consequently, leading to better genetic gains per unit of time.

For parameter $1 / \mathrm{k}$ and weight at different ages, genetic correlations tended to decrease as age increased, until 205 days of age, after which it increased as age increased, although with negative values. Considering the developmental period analyzed, it is suggested that selection at 205 days for shorter maturity intervals could lead to faster maturity rates and heavier mature weights. From this age on, or before it, selection for shorter maturity intervals could result in lighter animals at maturity. The integration constant (B) had low genetic correlations that grew with age, although they were negative until 205 days of age.

\section{CONCLUSIONS}

Low heritabilities found for both breeds, mainly for mature weight, age at inflection point of growth curve, weight at inflection point of growth curve and maturity interval, suggest that selection for growth based solely on phenotypic values of curve parameters may not lead to a satisfactory response.

Nelore animals grow faster with shorter maturity intervals, and reach mature weight younger than Chianina. Despite its slow maturity rates and longer maturity intervals, Chianina exhibited mature weights superior to those of Nelore. 
Table X

Estimates of genetic, phenotypic and environmental correlations between growth parameters estimated by the model of von Bertalanffy and weight at different ages for Chianina animals.

\begin{tabular}{|c|c|c|c|c|c|}
\hline \multirow[t]{2}{*}{ Parameters } & \multirow{2}{*}{$\begin{array}{l}\text { Weight at } \\
\text { different ages }\end{array}$} & \multicolumn{4}{|c|}{ Correlations } \\
\hline & & Genetic & Standard error & Phenotypic & Environmental \\
\hline \multirow[t]{7}{*}{ A - } & $\mathrm{BW}^{*}$ & -0.123 & 0.505 & 0.180 & 0.315 \\
\hline & P 090 & 0.026 & 0.412 & 0.099 & 0.219 \\
\hline & P 150 & 0.039 & 0.390 & 0.098 & -0.998 \\
\hline & P 205 & 0.042 & 0.387 & 0.138 & -0.593 \\
\hline & P 365 & 0.232 & 0.376 & 0.393 & 0.834 \\
\hline & P 455 & 0.316 & 0.367 & 0.539 & 0.856 \\
\hline & P 550 & 0.424 & 0.332 & 0.645 & 0.933 \\
\hline \multirow[t]{7}{*}{ B - } & BW & -0.323 & 0.479 & -0.198 & -0.124 \\
\hline & P 090 & -0.184 & 0.376 & -0.230 & -0.350 \\
\hline & P 150 & -0.160 & 0.351 & -0.163 & 0.879 \\
\hline & P 205 & -0.100 & 0.343 & -0.044 & -0.117 \\
\hline & P 365 & 0.114 & 0.352 & 0.366 & 0.977 \\
\hline & P 455 & 0.190 & 0.354 & 0.503 & 0.943 \\
\hline & P 550 & 0.258 & 0.344 & 0.550 & 0.920 \\
\hline \multirow[t]{7}{*}{ k - } & BW & 0.073 & 0.409 & 0.023 & -0.019 \\
\hline & P 090 & 0.441 & 0.277 & 0.287 & -0.025 \\
\hline & P 150 & 0.445 & 0.260 & 0.324 & 0.224 \\
\hline & P 205 & 0.476 & 0.253 & 0.306 & 0.421 \\
\hline & P 365 & 0.301 & 0.310 & 0.028 & -0.701 \\
\hline & P 455 & 0.186 & 0.342 & -0.154 & -0.753 \\
\hline & P 550 & 0.082 & 0.352 & -0.291 & -0.889 \\
\hline \multirow{7}{*}{$\mathrm{T}_{(\mathrm{I})}{ }^{-}$} & BW & -0.278 & 0.416 & -0.033 & 0.155 \\
\hline & P 090 & -0.575 & 0.334 & -0.255 & 0.358 \\
\hline & P 150 & -0.550 & 0.317 & -0.291 & -1.781 \\
\hline & P 205 & -0.539 & 0.312 & -0.268 & -0.854 \\
\hline & P 365 & -0.357 & 0.316 & -0.019 & 0.809 \\
\hline & P 455 & -0.259 & 0.328 & 0.144 & 0.798 \\
\hline & P 550 & -0.155 & 0.339 & 0.260 & 0.875 \\
\hline \multirow{7}{*}{$\mathrm{P}_{(\mathrm{I})}-$} & BW & -0.123 & 0.505 & 0.180 & 0.315 \\
\hline & Р 090 & 0.026 & 0.412 & 0.099 & 0.219 \\
\hline & P 150 & 0.039 & 0.390 & 0.098 & -0.998 \\
\hline & P 205 & 0.042 & 0.387 & 0.138 & -0.593 \\
\hline & P 365 & 0.232 & 0.376 & 0.393 & 0.834 \\
\hline & P 455 & 0.316 & 0.367 & 0.539 & 0.856 \\
\hline & P 550 & 0.424 & 0.332 & 0.645 & 0.933 \\
\hline \multirow[t]{7}{*}{$1 / \mathrm{k}-$} & BW & -0.261 & 0.401 & 0.011 & 0.245 \\
\hline & P 090 & -0.641 & 0.316 & -0.252 & 0.598 \\
\hline & P 150 & -0.615 & 0.304 & -0.316 & -2.645 \\
\hline & P 205 & -0.618 & 0.301 & -0.325 & -1.085 \\
\hline & P 365 & -0.452 & 0.311 & -0.140 & 0.693 \\
\hline & P 455 & -0.351 & 0.319 & 0.022 & 0.693 \\
\hline & P 550 & -0.244 & 0.325 & 0.153 & 0.804 \\
\hline
\end{tabular}

*BW- Birth weight.

Selection for heavier weights at inflection point of growth curve leads to increased mature weight, in both breeds, allowing for early estimates of the genetic potential of the animals, contributing to increased genetic gains per unit of time.

Considering the developmental period studied, from birth to 18 months, the results suggested that the practice of genetic selection for heavier weights at 150 and 205 days of age for Nelore and Chianina animals, respectively, leads to animals that grow with faster maturity rates and reach the maturity younger and heavier.
Nelore animals reach the age considered ideal for selection for growth characters younger than Chianina animals, implicating on reduction of the interval between generations on Nelore breed animals, allowing for greater annual genetic gains on that breed.

\section{ACKNOWLEDGMENTS}

The authors greatly thank Coordenação de Aperfeiçoamento de Pessoal de Nível Superior (CAPES) for their financial support that made this work possible. Publication supported by FAPESP. 


\section{RESUMO}

Foram analisados dados de pesagens do nascimento aos dezoito meses de idade de bovinos de corte das raças Nelore e Chianina. Os dados foram corrigidos para os efeitos significativos de meio ambiente e utilizados para estimar parâmetros de crescimento através do modelo não linear de von Bertalanffy. Os valores médios encontrados para os parâmetros de crescimento em Nelore foram: peso à maturidade (A), 312,87 kg; constante de integração (B), 0,49; taxa de maturidade (k), 0,13; idade ao ponto de inflexão $\left(\mathrm{T}_{(\mathrm{I})}\right), 3,29$ meses; peso ao ponto de inflexão $\left(\mathrm{P}_{(\mathrm{I})}\right), 92,70 \mathrm{~kg}$, e intervalo de maturidade $(1 / \mathrm{k}), 8,04$ meses. Para os animais Chianina os valores foram $751,38 \mathrm{~kg}, 0,59,0,10,6,64$ meses, $222,63 \mathrm{~kg}$ e 10,98 meses, respectivamente. Animais Nelore exibiram maiores taxas de maturidade, menores intervalos de maturidade, atingindo pesos à maturidade em idades mais jovens do que animais da raça Chianina, apesar de mais leves do que estes à maturidade. As estimativas de herdabilidade apresentaram valores baixos, principalmente para os parâmetros peso à maturidade $(0,093$ e 0,212$)$, idade ao ponto de inflexão $(0,062$ e 0,202), peso ao ponto de inflexão $(0,093$ e 0,212) e intervalo de maturidade $(0,057$ e 0,309) (para Nelore e Chianina, respectivamente). Os parâmetros peso à maturidade e peso ao ponto de inflexão mostraram correlações genéticas positivas com os pesos em diferentes idades e com tendências similares, sendo estas crescentes conforme aumentou-se a idade, em ambas as raças. Considerando o período de crescimento analisado, ou seja, do nascimento aos 18 meses de idade, o parâmetro taxa de maturidade e os pesos em diferentes idades mostraram correlações genéticas crescentes até os pesos às idades de 150 e 205 dias em Nelore e Chianina, respectivamente, decrescendo a partir destas idades e os valores das correlações genéticas entre o parâmetro intervalo de maturidade e os pesos em diversas idades apresentaram-se negativos, decrescentes até os pesos às idades de 150 e 205 dias, respectivamente, em Nelore e Chianina, e crescentes a partir destas idades.

\section{REFERENCES}

Bianchini Sobrinho, E. and Duarte, F.A.M. (1991). Modelos matemáticos aplicados ao crescimento de bovinos da Raça Nelore. In: Reunião Anual da Região Brasileira da Sociedade Internacional de Biometria, 36. Anais. Embrapa/UFG, Goiânia, pp. 24.

Brody, S. (1945). Bioenergetics and Growth. Reinhold Publishing Corporation, New York.

Brown, J.E., Brown, C.J. and Butts Jr., W.T. (1972). A discussion of the genetics aspects of weight, mature weight and rate of maturing in Hereford and Angus cattle. J. Anim. Sci. 34: 525-536.

Brown, J.E., Fitzhugh Jr., H.A. and Cartwright, T.C. (1976). A comparison of non linear models for describing weight-age relationships in cattle. J. Anim. Sci. 42: 810-818.

Bullock, K.D., Bertrand, J.K. and Benyshek, L.L. (1993). Genetic and environmental parameters for mature weight and other growth measures in Polled Hereford cattle. J. Anim. Sci. 71: 1737-1741.

Calo, L.L., McDowell, R.E., VanVleck, L.D. and Miller, P.D. (1973). Parameters of growth of Holstein-Friesian bulls. J. Anim. Sci. 37: 417-422.

DeNise, R.S.K. (1982). Relationships among the growth curve parameters and productivity traits in beef cows. Ph.D. thesis, Colorado State University, Colorado.
Draper, N. and Smith, H. (1966). Applied Regression Analysis. John Wiley, New York.

Duarte, F.A.M. (1975). Estudo da curva de crescimento de animais da raça "Nelore" (Bos taurus indicus), através de cinco modelos estocásticos. Associate Professor thesis, Departamento de Genética e Matemática Aplicada à Biologia, Faculdade de Medicina de Ribeirão Preto, Universidade de São Paulo, Ribeirão Preto, SP.

Fitzhugh Jr., H.A. (1976). Analysis of growth curves and strategies for altering their shape. J. Anim. Sci. 42: 1036-1051.

Harvey, W.R. (1987). Mixed Model Least-Squares and Maximum Likelihood Computer Program. Ohio State University, Ohio.

López De Torre, G. and Rankin, B.J. (1978). Factors affecting growth curve parameters of Hereford and Brangus cows. J. Anim. Sci. 46: 604-613.

López De Torre, G., Candotti, J.J., Reverter, A., Bellido, M.M., Vasco, P., García, L.J. and Brinks, J.S. (1992). Effects of growth curve parameters on cow efficiency. J. Anim. Sci. 70: 2668-2672.

McLaren, J.B., Morrow, R.E. and Butts Jr., W.T. (1982). Impact of numbers and frequency of weighings on bovine weight-age curve parameters. J. Anim. Sci. 54: 51-57.

Nelsen, T.C., Long, C.R. and Cartwright, T.C. (1982). Postinfection growth in straightbred and crossbred cattle. II. Relationships among weight, height and pubertal characters. J. Anim. Sci. 55: 293-304.

Northcutt, S.L. and Wilson, D.E. (1993). Genetic parameter estimates and expected progeny differences for mature size in Angus cattle. J. Anim. Sci. 71: 1148-1153.

Northcutt, S.L., Wilson, D.E. and Hoekstra, J.A. (1994). Effect of positive genetic trend for mature size on age-of-dam adjustment factors for weaning weight in Angus field records. J. Anim. Sci. 72: 828-832.

Nuru, S., Buvanendran,V. and Abed, S.M. (1981). Growth rates of Wadaradand Shorthorn-Wadara crossbred cattle in the northeastern of Nigeria. J. Anim. Prod. Res. 1: 123-124.

Perotto, D. (1992). Additive and nonadditive genetic effects on growth and milk production traits in Holstein x Ayrshire crossbreeding experimental data. Ph.D. thesis, Faculty of Graduate Studies and Research, McGill University, Montréal, PQ.

Perotto, D., Cue, R.I., Lee, A.J., McAllister, A.J., Batra, T.R., Lin, C.Y., Roy, G.L. and Wauthy, J.M. (1994). Additive and non-additive genetic effects of growth-curve parameters of Holstein, Ayrshire and crossbred females. Can. J. Anim Sci. 74: 401-409.

Quaas, R.L. (1983). Genetic variation in growth curves of Hereford females. Ph.D. thesis, Colorado State University, Colorado.

Richards, F.J. (1959). A flexible growth function for empirical use. J. Exp. Bot. 10: 290-300.

Souza, J.C. and Bianchini Sobrinho, E. (1994). Estimativa do peso de bovinos de corte, aos 24 meses, da raça Nelore, usando curvas de crescimento. Rev. Soc. Bras. Zoot. 23: 85-91.

Taylor, St. C.S. (1965). A relation between mature weight and time taken to mature in mammals. Anim. Prod. 7: 203-220.

Taylor, St. C.S. and Fitzhugh Jr., H.A. (1971). Genetic relationships between mature weight and time taken to mature within a breed. $J$. Anim. Sci. 33: 726-731.

Vaccaro, R. and Rivero, S. (1985). Growth of Holstein Friesian females in the Venezuelan tropics. Anim. Prod. 40: 279-285.

von Bertalanffy, L. (1938). A quantitative theory of organic growth. Hum. Biol. 10: 181-213.

Wada, Y. and Nishida, A. (1987). Genetic aspects of the growth curve characteristics in Japanese Black cows. Jpn. J. Zootech. Sci. 58: 10781085.

Wada, Y., Matsukawa, T. and Sasaki, Y. (1983). Describing weight-age relationships in Japanese Black females with non-linear growth models. In: World Conference on Animal Production, 5. Proceedings of the Japanese Society of Zootechnical Science, Tokyo, pp. 33-34.

Warwick, E.J. and Legates, J.E. (1979). Breeding and Improvement of Farm Animals. 7th edn. McGraw-Hill Book, New York.

(Received January 20, 1998 